\title{
Analisis Implikasi Permasalahan Wanprestasi dalam Kredit Perbankan (Studi Kasus Putusan MAHKAMAH AGUNG Nomor: 2337 K / PDT / 2009)
}

\author{
Analysis of The Implications of Default Problem in Bank \\ Credit (Studi Kasus Putusan MAHKAMAH AGUNG Nomor: \\ 2337 K / PDT / 2009)
}

\author{
Muhammad Nazim Husen* \& Said Rizal ** \\ Program Studi Ilmu Hukum, Fakultas Hukum, Universitas Prima Indonesia, Indonesia \\ Diterima: 06 Juli 2020; Disetujui: 02 Agustus 2020; Dipublish: 04 Agustus 2020 \\ Coresponding Email: * nazimhusen84@gmail.com, ** $\underline{\text { rizalsaid001@gmail.com }}$
}

\section{Abstrak}

Dalam hal ini nasabah (Debitor) membutuhkan sejumlah uang untuk modal usaha, sebagai jaminan nya Debitur tersebut menyerahkan surat sertifikat nya sebagai jaminan kepada PT. Bank Syariah Mandiri Denpasar (Kreditur) yang dalam hal ini lembaga keuangan perbankan yang kegiatan usahanya adalah memberikan bermacam-macam kredit kepada masyarakat. Artikel ini bertujuan untuk mengetahui dan menganalisa penyebab uang asuransi yang dibayarkan oleh pihak kreditur tidak sesuai dengan kesepakatan dengan debitur, di PT. Bank Syariah Mandiri Denpasar. Metode yang digunakan dalam penulisan ini yaitu penlitian bersifat yuridis normatif yaitu sebuah penelitian dimana penelitian yang ditunjukan terkait dengan peraturan baik yang tertulis ataupun bahan hukum yang lain. Dari Hasil penelitian menunjukkan bahwa pihak kreditur mengakui bahwa ada kesepakatan dengan debitur dengan dimuat di akad al-murabahah. Dalam akad tersebut dinyatakan bila debitur meninggal dunia maka seluruh utang debitur akan dibayarkan oleh asuransi jiwa sepenuhnya, dan debitur meninggal dunia , akan tetapi pihak kreditur hanya membayarkan asuransi jiwa selama 12 (dua belas) bulan, dikarenakan pihak debitur ada melakukan penunggakan pembayaran selama 6 (enam) bulan dan bulan berikutnya pihak debitur meninggal, hasilnya Sisa angsuran dari tenor semula 84 (delapan puluh empat) bulan yang dibayarkan berjalan 12 (dua belas bulan) oleh debitur tersebut harus dibayarkan kembali angsuran sampai waktu yang telah di sepakati kembali oleh pihak ahli waris dari debitur.

Kata Kunci: Sistem Kredit, Bank Syariah Mandiri Denpasar, Asuransi Jiwa, Wanprestasi.

\begin{abstract}
In this case the customer (debtor) requires a certain amount of money for the business capital, as a guarantee his debtor submit his certificate letter as collateral to the creditors which in this case is PT. BANK SYARIAH MANDIRI DENPASAR is a Bank financial institution that one of its business activities is to give credit to the community. This journal aims to know that the Bank Mandiri Denpasar has done the agreement to debtors, the method used in this writing normative juridical research is a study conducted or shown in the written rules or other legal materials. The results showed that the creditors admitted that there was an agreement with the debtor that was loaded in Akad al-Murabahah. The contract is stated if the debtor dies then all debtor's debts will be paid by full life insurance, and the debtor dies, but the creditor will only pay the life insurance for 12 (twelve) months, because the debtor has to do the payment rider for 6 (six) months and the next month the borrower dies, the result of remaining installment from the original tenor 84 (eighty four) months which is paid 12 (twelve months) by the debtor must be re-has been reagreed by the beneficiaries of the debtor.
\end{abstract}

Keywords: Credit System, Bank Syariah Mandiri Denpasar, Insurance, Breach of Contract

How to Cite: Husen, M.N. \& Rizal, S. (2018). Analisis Implikasi Permasalahan Wanprestasi dalam Kredit Perbankan (Studi Kasus Putusan MAHKAMAH AGUNG Nomor: 2337 K / PDT / 2009). Journal of Education, Humaniora and Social Sciences (JEHSS), 3 (1): 120 -124

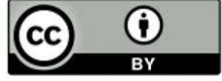




\section{PENDAHULUAN}

Pada umumnya di kehidupan masyarakat orang saling mengadakan relasi yang umumnya jumlah dan sifatnya yang sangat banyak. Masyarakat itu mempunyai kepentingan masing-masing dan masyarakat memungkinkan itu saling bertemu dan menjadi suatu kontak yang erat. Hubungan yang saling mendekatkan apabila kepentingan-kepentingan itu saling menguntungkan. Tentunya mudah untuk dipahami bahwa untuk mencapai suatu hubungan yang erat harus mengedepankan kepentingan pihak-pihak yang bersangkutan untuk itu harus ditimbulkan nya perjanjian.

Perjanjian di definisikan yaitu alat yang tak bisa dipisahkan bagi para pihak yang berkepentingan untuk mengkaitkan satu diri dengan yang lain dengan memenuhi hak dan kewajiban masing-masing pihak. Didalam hukum perjanjian juga dikenal asas kebebasan berkontrak yang intinya menentukan dimana setiap orang yang mengadakan perjanjian di perbolehkan untuk membuat ketentuan-ketentuan sendiri yang mengesampingkan dari pasal hukum perjanjian yang pihak tersebut adakan. Para pihak yang sepakat mengikatkan diri dalam suatu perjanjian terlebih dahulu mengkehendaki klausula yang sifatnya membatasi pertanggungjawaban berupa tuntutan ganti rugi yang di jabarkan keberlakuannya termasuk ketika salah satu pihak sesungguhnya telah melakukan wanprestasi atau melanggar perjanjian yang disepakati.

Sebagai contoh praktek penerapan paling lazim terkait pembatasan tanggungjwab ditemukan di kehidupan sehari-hari. Kasus paling sederhana misalnya dalam perjanjian pinjam meminjam antar debitur dan kreditur, dimana kreditur dalam klausula menyebutkan bahwa jika nasabah mengalami musibah antara lain meninggal dunia, pihak debitur bebas dari utang yang ada karena debitur membayar sejumlah uang untuk asuransi jiwa (Marpaung, dkk., 2016). Dengan demikian apabila pihak kreditur melakukan wanprestasi dan menyebabkan debitur mengalami kehilangan hak nya, pihak debitur boleh saja membuat pendalilan antara lain yaitu suatu perjanjian yang wajib untuk memberikan ganti rugi maksimal senilai nilai pertanggungan yang ditetapkan berdasarkan kesepakatan klasula yang ditetapkan oleh kedua belah pihak tersebut. Dalam hal ini yang menjadi patokan hukum bagi para pihak adalah ketentuan pasal 1313 Kitab Undang-Undang Hukum Perdata (KUHPerdata) yang mengatur sebagai berikut: "Suatu perjanjian adalah suatu perbuatan dengan mana satu orang atau lebih mengikatkan dirinya terhadap satu orang atau lebih (Kitab Undang-Undang Hukum Perdata pasal 1313)

Yang menjadi polemik dalam penerapan ini timbul ketika dalam kasus pemberlakuan klausula pembatasan tanggungjawab dalam hal terjadi wanprestasi tersebut di salah terapkan sebagai "perlindungan hukum" bagi pihak yang kurang beritikad baik. Contohnya apabila ada pihak yang kurang beritikad baik tersebut justru dengan sengaja melakukan wanprestasi atau ingkar janji dengan pertimbangan karena suatu kenikmatan atau akan mendapat keuntungan yang didapatkan di rasa lebih berfaedah dibandingkan dengan ketetapan berupa pertanggung jawaban yang dituntut ganti rugi yang jumlahnya telah ditetapkan atau di batasi sesuai dengan kesepakatan yang telah di perjanjikan di dalam klausula tersebut.

Adapun lembaga keuangan yang menyalurkan kredit kepada masyarakat antara lain adalah Bank. Dalam Pasal 1 angka 2 Undang-Undang No. 10 tahun 1998 tentang Perbankan yang dimaksud dengan Bank adalah badan usaha yang menghimpun dana dari masyarakat dalam bentuk simpanan dan menyalurkannnya kepada masyarakat dalam bentuk kredit dan atau bentuk-bentuk lainnya dalam rangka meningkatkan taraf hidup orang banyak (Undang-Undang No.10 tahun 1998 tentang Perbankan).

Pada peristiwa ini nasabah (Debitor) membutuhkan sejumlah uang untuk modal usaha, sebagai jaminan nya Debitur tersebut menyerahkan surat sertifikat nya sebagai jaminan kepada pihak Bank syariah (Kreditur) dalam hal ini adalah PT. Bank Syariah Mandiri Denpasar merupakan salah satu lembaga keuangan perbankan yang kegiatan usahanya salah satunya adalah memberikan kredit kepada masyarakat.

Lembaga keuangan bank memberikan persyaratan untuk suatu nilai pinjaman yang besar haruslah dilengkapi dengan tambahan asuransi jiwa guna meminimalisir risiko yang akan terjadi, untuk itu pihak debitur harus menyetujui dengan adanya kesepakatan tersebut. Setelah pihak 
debitur mengikatkan diri kepada kreditur dengan adendum yaitu pihak kreditur menerima sejumlah uang yang ditetapkan untuk asuransi jiwa dan pihak debitur menerima hak yaitu apabila terjadi risiko yang ditetapkan sesuai dengan kesepakatan maka pihak kreditur harus membayar seluruh utang dengan asuransi jiwa tersebut secara seluruhnya. Sesuai dengan uraian permasalahan latar belakang di atas masalah yang penulis teliti dan analisa dalam penelitian ini yaitu Apa yang menyebabkan uang asuransi jiwa nasabah hanya di bayarkan oleh Pihak Bank tidak sesuai dengan perjanjian kedua belah pihak dan Apa implikasi yang terjadi dari implementasi yang dilakukan oleh pihak bank Mandiri Syariah Denpasar tersebut.

\section{METODE PENELITIAN}

Penelitian yang dipergunakan dalam menyelesaikan penelitian ini yaitu jenis penelitian yang mengarah kepada penelitian yuridis normatif dimana sebuah penelitian yang dilakukan serta ditunjukan pada peraturan yang tertulis atau bahan hukum yang lain (Ali, 2014). Dalam penelitan ini penulis menggunakan metode pendekatan secara kuantitatif. Metode kuantitatif adalah metode penelitian yang dapat diartikan sebagai metode penelitan yang berlandaskan pada filsafat positivisme, digunakan untuk meneliti pada populasi atau sampel tertentu, pengumpulan data menggunakan instrument penelitian, analisis data bersifat kuantitatif dengan tujuan untuk menguji hipotesis yang telah ditetapkan (Sugiyono, 2013). Sifat penelitian yang digunakan dalam penelitian ini merupakan sebuah penelitian yang bersifat deskriptif analisis, karena dalam penelitian ini memberikan gambaran tentang data yang di peroleh secara sistematis, faktual dan akurat tentang implikasi wan prestasi yang dilakukan oleh pihak Perbankan (Bank Syariah Mandiri Denpasar). Adapun Sumber bahan hukum yang dipergunakan dalam penelitian ini adalah data Sekunder yaitu data yang diperoleh dari penelitian terdahulu.

Data Sekunder Terbagi dalam 3 bagian yaitu: Bahan Hukum Priemer, yakni merupakan sumber bahan hukum yang bersifat autoritatif, yaitu seperti perundang-undangan; Bahan Hukum Sekunder, yakni berupa data - data yang di peroleh atau yang merupakan dokumen resmi. Bahan hukum yang digunakan dalam penelitian ini adalah Buku-buku, literatur, Karya ilmiah / Jurnal yang berkaitan dengan penelitian ini.

Baha Hukum Tersier, yakni bahan bahan hukum yang berfungsi menyertakan sebuah penjelasan serta pemahaman terhadap bahan hukum priemer dan bahan hukum sekunder, yakni antara lain perundang-undangan, buku terkait hukum perjanjian dan perikatan, putusan pengadilan, internet dan lain sebagainya.

Teknik pengumpulan data yang dipergunakan dalam penelitian ini, yakni menggunakan sebuah penelitian kepustakaan yang mengkaji serta meneliti peraturan perundang-undangan, buku-buku baik dari koneksi pribadi maupun dari perpustakaan, artikel-artikel baik dari media cetak maupun media elektronik, makalah ilmiah dan bahan-bahan lainnya yang tentunya berhubungan erat dengan materi yang dibahas dalam penelitian ini.

Analisis data merupakan sebuah proses yang mencoba mengorganisasikan dan mengurutkan data kedalam sebuah pola, kategori dan satuan uraian dasar sehingga dapat ditemukan sebuah tema serta dapat juga dirumuskan suatu hipotesis kerja seperti yang disarankan data (Moleong, 2007). Analisis secara Kualitatif yaitu: Mengumpulkan bahan hukum berupa inventarisasi peraturan perundang-undangan yang relevan dan bahan-bahan kepustakaan lainnya yang mendukung. Memilah bahan hukum yang sudah dikumpulkan dan selanjutnya melakukan sistematisasi bahan-bahan hukum sesuai dengan permasalahan. Menganalisis bahan hukum dengan membaca dan menafsirkan untuk menemukan kaidah, asas, konsep yang terkandung di dalam bahan hukum tersebut.

\section{HASIL DAN PEMBAHASAN}

\section{Hubungan Hukum Antara Bank Syariah Dan Nasabah}

Dalam Undang-Undang Nomor 21 Tahun 2008 Tentang Perbankan Syariah pasal 1 ayat 16 yang di maksud nasabah bank syariah adalah pihak yang menggunakan jasa bank syariah dan/atau Undang-Undang Syariah. Nasabah bank syariah (Usantia \& Shomad, 2017; Isnaini. 2019; 
Miftahuddin, 2019; Isnaini, \& Barus, 2017; Khalid, dkk., 2018; Harahap dan Wahyuni, 2016) terbagi menjadi:

1. Nasabah penyimpanan adalah nasabah yang menempatkan dananya di bank syariah dan / atau Undang-Undang Syariah dalam bentuk simpanan berdasarkan akad antara bank syariah atau undang-Undang Syariah dan nasabah yang bersangkutan.

2. Nasabah penerima fasilitas adalah nasabah yang memperoleh fasilitas dana yang dipersamakan dengan itu, berdasarkan prinsip syariah.

3. Nasabah investor adalah nasabah yang menempatkan dananya di bank syariah dalam bentuk menanamkan sejumlah uang besrdasarkan akad antara bank syariah dan nasabah yang bersangkutan.

Penyebab uang asuransi jiwa nasabah tidak di bayarkan oleh pihak krediur tidak sesuai dengan kesepakatanyang dibuat oleh kedua belah pihak sesuai dengan permohonan Kasasi Dalam putusan Nomor: 2337 K/PDT/2009

Bahwa dengan di terbitkannya persetujuan No. 01/034/SP3/01.05 Januari tanggal 12 tahun 2005 dimana pihak debitur dan pihak kreditur menyetujui perihal pemberitahuan persetujuan pembiayaan. Pihak kreditur dengan ini mempunyai kewajiban membayar asuransi jiwa atas nama nasabah. Kemudian di surat persetujuan tersebut dinyatakan bahwa apabila pihak kreditur akan membayarkan asuransi jiwa jika terjadi terjadi resiko meninggalnya pihak debitur. Ternyata risiko tersebut benar terjadi dimana pihak debitur meninggal dunia. Sehingga pihak debitur akan melakukan pelelangan surat-surat yang menjadi jaminan debitur pada saat akad tersebut.

Sehingga penulis berpendapat bahwa alasan pihak bank tidak membayarkan seluruh uang asuransi tersebut karena dalam hal ini alm. Kusyadi dalam perjanjian akad murobahah baru membayar premi selama 1 tahun dan pada bulan berikutnya mengalami penunggakan. Merujuk pada pasal 1243 KUHPerdata penggantian biaya, rugi dan bunga karena tak dipenuhinya suatu perikatan, barulah mulai diwajibkan, apabila si berutang setelah dinyatakan lalai memenuhi perikatannya, tetap melalaikannya, atau jika sesuatu yang harus diberikan atau dibuatnya, hanya dapat diberikan atau dibuat dalam tenggang waktu yang telah dilampauinya (pasal 1243 Kitab Undang-Undang Hukum Perdata.

Debitur dinyatakan lalai apabila:

1. Tidak memenuhi prestasi.

2. Terlambat berprestasi.

3. Berprestasi tapi tidak sebagaimana mestinya (Handoko, 2010,)

4. Namun demikian pada umumnya wanprestasi baru terjadi setelah ada pernyataan lalai (In mora stelling ingebereke stelling) dari pihak kreditur kepada debitur.

Merujuk ke Akad Pembiayaan AlMurabahah tertanggal 19 Januari 2005 jangka waktu kredit yaitu sampai dengan tanggal 19 Januari 2012 dan berdasarkan akad tersebut tertulis: pihak debitur berjanji dan dengan ini mengikatkan diri untuk membayar kembali seluruh utangnya dengan jumlah yang semestinya di lunasi

Adapun terkait masalah ini penulis mengkaitkan dengan pasal 1239 BW, yang menyatakan bahwa "Tiap perikatan untuk berbuat sesuatu atau untuk tidak berbuat seuatu, wajib diselesasikan dengan memberikan penggantian biaya, kerugian dan bunga bila debitur tidak memenuhi kewajibannya." (Pasal 1239 Kitab undang - undang hukum perdata (burgerlijkwetboek)

\section{Implikasi Dari Implementasi yang Dilakukan Oleh Pihak Bank Terhadap Nasabah}

Sesuai dengan perjanjian sebelumnya antara alm. Kusyadi dan pihak Bank Mandiri pada tanggal 19 Januari 2005 tertulis bahwa pihak Bank boleh melakukan tindakan melelang atau menjual barang yang menjadi jaminan jika dikemudian hari telah terjadi peristiwa - peristiwa hukum yang telah diuraikan di pasal akad al-murabahah tersebut. Yang mana makna dari pasal tersebut yang penulis analisa adalah pihak bank ingin melelang harta jaminan karena pihak nasabah tidak melanjutkan pembayaran angsuran selama 67 (enam puluh tujuh bulan) dengan itu nasabah harus membayar kembali angsuran. Artinya pihak nasabah masih mempunyai waktu 
untuk melakukan pembayaran tersebut. Sehingga dampak yang di alami oleh Nasabah (penggugat) sangat merasa rugi dikarenakan pihak Penggugat merasa tidak pernah menerima No. Polis asuransi jiwa tersebut terhadap pihak Bank. Akan tetapi pihak Penggugat harus membayar angsuran berserta premi asuransi jiwa yang menurut akad al murabahah pasal tersebut harus di penuhi. Sehingga penulis menganalisa pihak bank tetap berkeyakinan bahwa Hubungan antara pihak kreditur dengan debitur adalah hubungan kontraktual dalam hal ini kontrak perjanjian pembiayaan konsumen. Apabila debitur tersebut tidak tepat waktu dalam melaksanakan kewajibannya maka debitur tersebut wanprestasi (Sutarjo dan Djuwityastuti, 2018).

\section{SIMPULAN}

penulis berpendapat dan menyimpulkan bahwa alasan pihak bank tidak membayarkan seluruh uang asuransi tersebut karena dalam hal ini alm. Kusyadi dalam perjanjian akad murobahah baru membayar premi selama 1 tahun dan pada bulan berikutnya mengalami penunggakan. Merujuk pada pasal 1243 KUHPerdata penggantian biaya, rugi dan bunga karena tak dipenuhinya suatu perikatan, barulah mulai diwajibkan, apabila si berutang setelah dinyatakan lalai memenuhi perikatannya, tetap melalikannya, atau jika sesuatu yang harus diberikan atau dibuatnya, hanya dapat diberikan atau dibuat dalam tenggang waktu yang telah dilampauinya (pasal 1243 Kitab Undang-Undang Hukum Perdata.

\section{DAFTAR PUSTAKA}

Ali, Z, (2014). Metode Penelitian Hukum. Jakarta: Sinar grafika.

Harahap, D.A dan Wahyuni, W.S. (2016), Peranan Urgensi Pengaturan Hukum Efek Syariah dalam Peraturan Perundang-Undangan di Indonesia, Jurnal Pendidikan Ilmu-Ilmu Sosial, 8 (2) (2016): 156-164

Hernoko, A.Y. (2010). Hukum Perjanjian Asas Proporsionalitas dalam Kontrak Komersial. Jakarta: Kencana. Isnaini, I., \& Barus, U. (2017). Pelaksanaan Akad Pembiayaan Mudharabah Di Bank Sumut Syariah Kota Medan. JURNAL MERCATORIA, 8(2), 145-162. doi:https://doi.org/10.31289/mercatoria.v8i2.653

Isnaini. (2019). Pelaksanaan Jaminan Pembiayaan Mudharabah Di Bank Syariah. JUPIIS: Jurnal Pendidikan Ilmu-ilmu Sosial, 11 (2): 228-247.

Khalid, K., Yahya, A., \& Darmawan, D. (2018). Pelaksanaan Pembiayaan Akad Murabahah Pasca Konversi PT. Bank Aceh Menjadi PT. Bank Aceh Syariah. JURNAL MERCATORIA, 11(2), 159-173. doi:https://doi.org/10.31289/mercatoria.v11i2.1636

Marpaung, B. Arifin.S, \& Hidayani, S (2016). Tinjauan Yuridis Akibat Hukum Terhadap Wanprestasi Dalam Perjanjian Kredit (Studi Putusan Nomor 607/Pdt.G/2013/ Pn.Mdn) Jurnal Ilmiah Penegakan Hukum, 3 (2) 2016: 114- 120

Miftahuddin. (2019). Perbandingan Konsep Keuangan pada Bank Syariah dan Bank Konvensional. Journal of Education, Humaniora and Social Sciences (JEHSS). 2 (2): 213-228.

Moleong, L.J. (2007). Metodologi Penelitian Kualitatif. Bandung: PT. Remaja Rosda Karya.

Sugiyono, (2013). Metode Penelitian Kuantitatif dan Kualitatif dan R \& G. Bandung: Alfabeta.

Sutarjo, A.Y. \& Djuwityastuti. (2018). Privat Law, Akibat Hukum Debitur Wanprestasi Pada Perjanjian Pembiayaan Konsumen Dengan Objek Jaminan Fidusia Yang Disita Pihak Ketiga. . Volume 6 (1): 93

Usanti, T.P. \& Shomad, A, (2017). Hukum Perbankan. Depok: Kencana

Kitab Undang - Undang Hukum Perdata/ Burgelijk Wetboek, Stb. 1847-23.

Undang-Undang Nomor 7 Tahun 1992 Tentang Perbankan sebelum (10/1998).

Undang-Undang Nomor 10 Tahun 1998 Tentang Perbankan.

Undang-Undang Nomor 21 Tahun 2008 Tentang Perbankan Syariah. 